\title{
Ajan merkkejä
}

Saattaa tuntua omituiselta, että tänä jäiden lähdön aikakautena, kolmannen tasavallan kynnyksellä, joudutaan kantamaan huolta sanan- ja ajatuksenvapauden kohtalosta. Kyse ei ole vain Orwellin vuodesta 1984, joka antaa mahdollisuuden poliittis-ideologisen propagandan tekoon, kylmän sodan teemojen uudelleen lämmittelyyn reaganilaisen ristiretken siivellä.

Erikoistutkija Nurmen tapaus, jota Antero Jyränki analysoi jälkikirjoituksessa, on herättänyt runsaasti sensaationmakuista huomiota. Asian periaatteellista puolta, tutkimuksen julkisuutta, tutkimuksen ja byrokratian välisiä suhteita jne. käsitelleitä puheenvuoroja ei päivälehdistössä ole juuri näkynyt, paria ilahduttavaa poikkeusta lukuunottamatta. Huolestuttavinta on tutkijayhteisön vaitonaisuus; tutkijoiden luulisi heräävän, kun tutkimuksen erästä elinehtoa, tutkimustulosten julkistamisoikeutta, pyritään kaventamaan. Onko ennustajaeukko-puhe tehnyt tehtävänsä?

Outoa myös on, että 15 vuotta Schüller-oikeudenkäyntien jälkeen ajatuksen vapautta joudutaan tässä maassa puolustamaan vankilassa istumalla. Lähes yhtä outoa on, että juuri kukaan ei reagoi, kun tasavallan valtalehdet pääkirjoituksissaan rinnastavat aseista ja veroista kieltäytyjät tai kiistävät vankilaan tuomitun aseista kieltäytyjän olevan mielipidevanki, koska tämä on tutkittu ja tuomittu Suomen lakien mukaisesti. Ajatuksen vapaudenkin ensimmäisten puolustajien luulisi löytyvän tutkijoiden joukosta.

Kettil Bruun on eräs niistä harvoista suomalaisista tutkijoista, jotka uskaltavat korottaa äänensä tutkimuksen tai ajatuksen vapauden loukkauksia vastaan. On paikallaan lainata hänen syntymäpäivähaastattelussaan esittämiään perusteluja erään vankilaan suljetun aseistakieltäytyjien ryhmän, Jehovan todistajien, tukemiselle: "Itse en ole jehovalainen. En tunne edes sympatiaa Jehovaa kohtaan, mutta olen järkyttynyt suomalaisten yhteiskunnan suvaitsemattomuudesta ja sietokyvyn puutteesta vähemmistöjä kohtaa." Skål, Kettil!

Ei ollut sattuma, että Kettil Bruunin juhlaseminaarin aiheena oli tutkijan vastuu ja etiikka. Samaa aihetta sivuaa lehdessämme Mika Böökin artikkeli, joka toivottavasti antaa uusia aineksia pohdinnoille tutkijoiden paikasta ja tehtävistä niin ydinsota- kuin ekokatastrofinkin torjumiseksi käytävässä kamppailussa. Böökin artikkeli koskettelee myös kysymyksiä tutkijoiden ja yleensäkin sivistyneistön suhteesta politiikkaan, vasemmistointellektuellien identiteettiongelmia; näitä kysymyksiä sivutaan myös Lucien Sèven haastattelussa. Böökin artikkeli ja Sèven haastattelu täydentävät näiltä osin toisiaan: ranskalaisen vasemmistosivistyneistön tämän päivän ongelmien juurien voinee väittää olevan Böökin kuvaamassa ajanjaksossa.

Suomalaisen sivistyneistön katseet näyttävät tänä päivänä suuntautuvan yhä useammin Ranskaan. Myös lehtemme tähän numeroon on miltei huomaamatta muodostunut eräänlainen Ranska-kokonaisuus; ajan merkkejä tämäkin. Silti toivoisi, että nykyisessä Ranska-innostuksessa säilyisi myös tietty viileä kriittisyys: koko sopulilauman ei soisi seuraavan Gallian kukkojen kulloisiakin askelmerkkejä. 
Suomalaisessa Ranskan tilanteesta käydyssä keskustelussa on jo alettu puhua marxismin kriisin sijasta ranskalaisen marxismin itsemurhasta. Lucien Sèven haastattelu ehkä hieman tasapainottaa sitä kuvaa, mikä Ranskan intellektuaalisesta ilmapiiristä Suomeen on välittynyt. Joka tapauksessa ja viimevuotisista muistokirjoituksista huolimatta: jäitä hattuun! Aseiden kieltäjiä tarvitsemme, itsensä kieltäjiä emme.

Lehteämme tekee uusi toimitus. Paras tapa kiittää Sakari Hännistä päätoimittajan työstään on jatkaa keskustelua niistä teemoista, jotka hän nosti esille ensimmäisessä pääkirjoituksessaan: kapitalismikritiikki, historiallisuus, marxismi, tieteellisen työn luonne, kansainvälisyys ja rauha. Käsiteltävien teemojen esimerkkilistaa voi vielä jatkaa: työ ja teknologia; luokkatutkimus; demokratia; modernin käsite; naisten historia ja naiskulttuuri.

Vanhan toimituksen ohella kiitokset kuuluvat myös toimitusneuvostolle. Erillistä toimitusneuvostoa lehdelle ei enää ole valittu. Toimitusneuvosto on ollut eräänlainen lehden lukijoiden ja tukijoiden edustusto. Pyrimme kehittelemään toimivampia muotoja sen vuorovaikutuksen ylläpitämiseksi, jota vailla Tiede\&edistys ei ole sitä, mitä sen pitäisi olla: lukijan ja tekijän roolit yhdistävä, avoin ja kriittinen, tutkimuksellisen panoksen suomalaiseen keskusteluun tuova julkaisu.

\section{Tutkijan vapaus hallintokoneistossa: Tri Markku Nurmen asia}

\section{Tapausten kulku}

Elinkeinohallituksen tutkimusosaston sopimuspalkkainen erikoistutkija, tekniikan tohtori Markku Nurmi sai vuoden 1982 alussa esimiehiltään tehtäväksi tutkia sähkön ja kaukolämmön hinnanmuodostusta. Työssään tri Nurmi vähitellen päätyi sellaiseen tulokseen, ettei sähkön nykyinen hinnoittelu perustu todellisiin tuotantokustannuksiin. Nurmen mukaan Imatran Voima Oy, joka sähkön myyjänä on valtakunnan ykkönen, oli pitkän aikaa perinyt sähköstä ylihintaa voidakseen varautua viidennen ydinvoimalan investointeihin. Kun Markku Nurmi esitteli tutkimustaan osastopäällikölleen ja virastonsa pääjohtajalle, nämä vaativat korjauksia tutki- 